\title{
THE EVALUATION OF COMPETENCY CERTIFICATION PROGRAM THROUGH THE LSP P-1 AT VOCATIONAL HIGH SCHOOL
}

\author{
Budiyanto $^{1 *}$, Wardan Suyanto ${ }^{1}$ \\ ${ }^{1}$ Universitas Negeri Yogyakarta \\ Jl. Colombo No. 1, Karangmalang, Depok, Sleman, Yogyakarta 55281, Indonesia
}

\begin{abstract}
This research aims to evaluate the competency certification program's implementation through the First-Party Professional Certification Institute (LSP P-1) at SMKN 2 Klaten. The evaluation of the implementation of the competency certification program was reviewed on four aspects, e.g.: (1) context, (2) input, (3) process, and (4) product. This research is evaluation research based on the CIPP model (Context, Input, Process, Product). This research was conducted at SMK N 2 Klaten, which already had an LSP P-1license. The respondents were the principal, LSP chairman, secretary, treasurer, certification manager, chairman of the scheme committee, the competency test venue (TUK), and assessors. A questionnaire was used to collect data in this study. The data were analyzed with descriptive analysis. The result shows that: (1) the implementation of competency certification test through the LSP P-1 at State Vocational High School 2 Klaten in the context aspect is classified as very appropriate (83.93\%), it is related to the policies and the goals of competency certification test; (2) in the input aspect is classified as very appropriate (88.82\%), which meet the criteria of the assessor and the completeness of assessment tools; (3) in the process aspect is classified as very appropriate (88.59\%), which leads to the suitability of the implementation procedures; and (4) in the product aspect is classified as very high (78.4\%), for the achievement of competency certification test results and competency certificates.
\end{abstract}

Keywords: program evaluation, CIPP, competency certification, LSP P-1

How to cite: Budiyanto, B., \& Suyanto, W. (2020). The evaluation of competency certification program through the LSP P-1 at vocational high school. Jurnal Pendidikan Vokasi, 10(1), 44-55. doi:https://doi.org/10.21831/jpv.v10i1.30155

*Corresponding Author: Budiyanto by434178@gmail.com

Department of Technology and Vocational Education, Graduate School, Universitas Negeri Yogyakarta Jl. Colombo No. 1, Karangmalang, Depok, Sleman, Yogyakarta 55281, Indonesia 


\section{INTRODUCTION}

State Vocational High School 2 Klaten or Sekolah Menengah Kejuruan Negeri (SMK N) 2 Klaten is a four-year vocational high school. Before graduation, students must take the industrial field practice for six months after the final exam. SMK N 2 Klaten currently has several competency skills, among others: computer and network engineering; automotive light vehicle engineering; building construction, sanitation and maintenance; electrical power installation engineering; audio-video engineering; mechanical engineering; design modeling and building information; metal casting engineering.

SMK N 2 Klaten serves and prepares its students to become fully Indonesian people. Students who are able to improve the quality of life, develop themselves so that they can create jobs, have expertise so that they become productive workforce, the courage to open opportunities, increase income, meet the needs of business and industry workforce, prepare students to master science and technology. According to Kuswana (2013, p. 34), a person is required to have the ability to cooperate and deal with others, based on a combination of the ability to work together and communicate. Through the Ministry of Education and Culture, the government is currently encouraging all vocational students to get competency certificates. According to Colardyn (2009, p. 2778), certification is a recognition of competence. This is made clear by Tissot (2004), who states that certification is a formal process for validating the knowledge, skills, and competencies obtained by an individual by following the standard assessment procedures that have been applied. The results of the certification process are stated in certificates or certificates issued by accrediting bodies. To support this program, while 327 SMKs have obtained licenses from BNSP to establish LSP P-1 (Ministry of Education and Culture, 2017).

The number is still small compared to the number of SMK graduates each year. There are mechanisms and provisions for an institution to become a First-Party Professional Certification Agency or Lembaga Sertifikasi Profesi Pihak 1 (LSP P-1). There are several problems faced by SMKs in implementing competency tests through LSP P-1, one of which occurred in SMK N 2 Klaten. The implementation of LSP P-1 will be successful if it meets the requirements, one of which is by having a technical assessor determined based on the BNSP Regulation No. 10/BNSP. 303/XI/2013. According to Rizkiyah et al. (2018, p. 709), assessors came from productive teachers who attended training as assessors. Yusuf and Mukhadis (2018, p. 131) added that productive teachers are teachers who have competency certificates by their expertise and are published by BNSP. The competency test through LSP P-1 will be successful if there are professionalism and integrity of the assessor. Based on observations at SMK N 2 Klaten the LSP P-1 implementation process should require a technical assessor for each study program, but currently, there are no assessors in the technical field. It happened because there were still constraints in training costs.

The Competency Test Place or Tempat Uji Kompetensi (TUK) is one of the requirements that must be met in implementing the competency certification program. According to Suharto (2015, p. 39), the Competency Test Place (TUK) or Assessment Center is a good workplace or workplace simulation for conducting competency tests or assessments by Professional Certification Institutions. In the TUK at SMK N 2 Klaten, until now, there is still some competency expertise that does not meet the requirements. This happens because of the procurement of facilities and infrastructure. At SMK N 2 Klaten, there are eight expertise competencies, six expertise competencies that have fulfilled TUK requirements, and there are two expertise competencies that have not yet met TUK requirements, namely Computer and Network Engineering and Metal Casting Engineering. Certainly, it is not easy in the procurement and will require substantial costs because the assessment centers are good workplaces or workplace simulations under industry environmental standards for conducting competency tests by competency certification agencies. TUK recognition is obtained through verification by BNSP after an assessment of compliance with BNSP guidelines, and technical requirements is conducted.

The TUK is ensured and maintained by LSP through annual survey activities. TUK also needs to be developed to ensure the implementation of competency tests carried out in the workplace so that the achievement of competence is truly contextual with the environment, facilities, and workplace infrastructure. The Competency Test Place benefits are for educational and training 


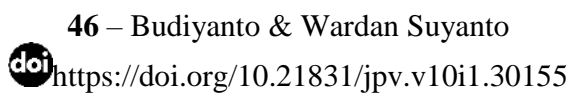

institutions; for industry; for labor; for professional certification bodies. In fact, the implementation of competency certification in SMK N 2 Klaten has not been able to be carried out by all majors, three majors have not met the requirements regarding TUK, so the implementation of competency tests is carried out for majors that have met the requirements.

The implementation of competency certification must meet the requirements set by the BNSP. It has been mentioned in the BNSP Regulation No. 1/BNSP/III/2014 on its attachment No. 201 regarding the scope of general requirements, including requirements for LSP, organizational structure, resources, records and information, certification schemes, certification processes, and management systems. According to Rodin (2015, p. 16), competence is defined as a benchmark to determine the extent to which a person's ability to use knowledge and abilities. Furthermore, Dobson (2003, p. 9) said that work competencies aim to ensure sufficient and adequate workforce skills to support international trade and competitiveness and provide opportunities for individuals to optimize their potential. Based on observations at SMK N 2 Klaten, there needs to be an evaluation of the competency certification program's implementation through the LSP P-1, because until now, there has been no research or study regarding this program. With the evaluation, information on the program's implementation will be obtained, then the information obtained will be reviewed and studied. The study results in the form of conclusions can be taken into consideration for the sustainability of the program.

Based on those statements, the research questions raised are (1) how is the suitability of implementing competency certification through LSP P-1 in SMK N 2 Klaten from the context aspect; (2) how is the suitability of the implementation of competency certification through LSP P-1 in SMK N 2 Klaten from the input aspect; (3) how is the implementation of competency certification through LSP P-1 in SMK N 2 Klaten from the aspect of the process; (4) how is the achievement of competency certification through LSP P-1 in SMK N 2 Klaten from the product aspect.

\section{RESEARCH METHOD}

This study is a program evaluation research using a quantitative approach, with ex-post facto type. The evaluation model in this research is CIPP. The use of the CIPP model is intended to determine the suitability and level of success of the implementation of the competency certification program through the LSP P-1 at SMK N 2 Klaten. This is done to improve and enhance the implementation of subsequent programs. The research setting is at SMK N 2 Klaten, which has been licensed by the National Professional Certification Board or Badan Nasional Standar Pendidikan (BNSP) and has implemented competency certification. This research was conducted in July-September 2019. The subjects and respondents in this research were all parties related to the implementation of the competency certification program through the LSP P-1 at SMK N 2 Klaten, namely the school principal as the person in charge/board of supervisors, secretaries, treasurers, the certification manager, the chair of the scheme committee, the head of the LSP, the head of the TUK, and the assessors. Data collection techniques in this research used a questionnaire to obtain data regarding the preparation, implementation, and benefits of the program. Data were analyzed using descriptive statistics, namely calculating mean (M), median, mode, and standard deviation (SD), data distribution tables, and category charts in sentences.

\section{RESULTS AND DISCUSSION}

\section{Evaluation of Competency Certification Test through The LSP P-1 at SMK N 2 Klaten: Review of the Aspect of Context}

The competency certification data from the context aspect was obtained from a questionnaire instrument given to the principal as the person in charge/board of supervisors, secretary, treasurer, certification manager, chair of the scheme committee, chair of the LSP, head of the TUK, and assessors. The indicator contains the objectives of competency certification. The instrument has 12 statements. Descriptive statistical data from the context aspect obtained in this research can be seen in Table 1. 
Table 1. Descriptive Statistics of Context Aspect

\begin{tabular}{ccccc}
\hline Mean & Median & Mode & Standard Deviation & Skewness \\
\hline 40.29 & 40 & 40 & 1.92 & 0.228 \\
\hline
\end{tabular}

Based on Table 1, it can be seen that the mean value in the context aspect is more than the median value, and the median value is the same as the mode value so that the distribution data is positive/right sloping. The size of the skewness is 0.228 . For valuation, the value is changed to the ratio number. The skewness ratio is $=$ skewness value/standard skewness error $=0.228 / 0.285=0.8$. Therefore, because the skewness ratio is between -2 to +2 , the data distribution is normal. The frequency distribution data from the context aspects which are obtained in this research is presented in Table 2.

Table 2. Frequency Distribution in Context Aspect

\begin{tabular}{|c|c|c|c|}
\hline Interval & Category & $\mathbf{F}$ & $\%$ \\
\hline$X<24.00$ & Very Low & 0 & 0 \\
\hline $30 \geq X \geq 24.00$ & Low & 0 & 0 \\
\hline $36.00 \geq X \geq 30$ & High & 1 & 2.9 \\
\hline$X \geq 36.00$ & Very High & 33 & 97.1 \\
\hline \multicolumn{2}{|c|}{ Amount } & 34 & 100 \\
\hline
\end{tabular}

Based on Table 2, $0(0 \%)$ of respondents are in the category of very low or strongly disagree; $0(0 \%)$ of respondents are in a low category or did not agree; $1(2.9 \%)$ of respondents are in the high category or agree; and $33(97.1 \%)$ of respondents are in the very high category or strongly agree. The value of achieving competency certification quality through LSP P-1 at SMK N 2 Klaten from the context aspect can be seen in Table 3.

Table 3. Value of Achieving Quality Context Aspect

\begin{tabular}{ccccc}
\hline Number of Respondents & Number of Statements & NPK & \% & Category \\
\hline 34 & 12 & 40.29 & 83.93 & Very High \\
\hline
\end{tabular}

Based on Table 3, it can be seen that competency certification in terms of context is included in the very high category with a quality achievement score of 40.29 , and a percentage of $83.93 \%$. Scales 1 to 4 are applied to assess competency tests in context aspects. Data on the value of quality achievement in the context aspect can be seen in Table 4 .

Table 4. Quality Achievement Value in the Context Aspect Indicator

\begin{tabular}{lcccc}
\hline \multicolumn{1}{c}{ Indicator } & Item & Value & Total Value & Category \\
\hline Policies and Objectives of & 1 & 4 & 3.5 & High \\
Competency Certification Test & 2 & 3.5 & & \\
Through LSP P-1 & 3 & 3.5 & & \\
& 4 & 3.4 & & \\
& 5 & 3.4 & & \\
& 6 & 3.3 & & \\
& 7 & 3.3 & & \\
& 8 & 3.4 & & \\
& 9 & 3.5 & & \\
& 10 & 3.3 & & \\
& 11 & 2.79 & & \\
& 12 & 2.58 & & \\
\hline
\end{tabular}

Based on Table 4, the policy indicator items and competency certification objectives that have the lowest value of 2.58 are job opportunities for competency certification graduates through LSP P-1 in the international industry. The highest score of 4 is that the purpose of the competency certification test is to gain recognition of the competencies possessed by the assessor. From these results, it is known that the policies and objectives in the competency certification test are in the 
good/high category. Respondents stated strongly agree that competency certification is an effort to recognize prospective workers' competencies. Competency certification is an effort to test students' ability and quality, whether competent or not competent, against the established competency standards.

On the item demands for job opportunities for graduates of LSP P-1 competency certification in the international industry, the item that has the lowest quality value is 2.58 . This means that the suitability of competency certification with students' employment opportunities through LSP P-1 on an international scale is still very low. In addition, according to the respondents, the competency certification cannot yet reflect students' competence to enter the international scale industry. The employment opportunities of LSP P-1 graduates are still only in the local scale industry, even for the national scale, it is still low. The suitability of the competency certification test through LSP P1 at SMK N 2 Klaten in terms of the context of the policy aspects and objectives of competency certification has a value of achieving quality indicators of 3.5.

According to Yusuf (2008, p. 14), context evaluation can help plan decisions, determine the needs to be achieved by the program, as well as formulate program goals. Further, Stufflebeam and Zhang (2017, p. 23) state that context evaluation produces information about environmental dynamics which are beneficial for program implementation. The results show that competency certification is very much in line with the policy and also competency certification objectives. However, there is still a need to adjust between competency certification and job opportunities for LSP P-1 graduates. Based on the results of the study in terms of the context, the competency certification test is an attempt in order to recognize the competencies of prospective workers. Competency certification is developed based on the Indonesian National Standard of Working Competence or known as Standar Kompetensi Kerja Nasional Indonesia (SKKNI) and also the business world and industrial world or Dunia Usaha-Dunia Industri (DUDI) development. The output of competency certification is adjusted to the needs of this DUDI in order to increase the opportunities for employment.

\section{Evaluation of Competency Certification Test through the LSP P-1 at SMK N 2 Klaten: Review of the Aspect of Input}

This is in line with the vocational high school's objectives, and the purpose of work competency certification data on the competency certification component from the input aspect was obtained from the instrument in the form of a questionnaire. Respondents are all parties that are involved in the implementation of the LSP P-1, consisting of the principal as the person in charge/ board of supervisors, secretaries, treasurers, certification managers, chair of the scheme committee, chair of the LSP, head of the TUK, and also assessors. The indicators contained in the input aspect are the Assessor, the Competency Test Material/Test Equipment Material, the Competency Test Site, Facilities, and Infrastructure. Data on this component were obtained from the results of the questionnaire that is given to 71 respondents. The questionnaire has 26 statements. Descriptive statistical data from the input aspects which are obtained in this research is clearly presented in Table 5.

Table 5. Descriptive Statistics of Input Aspect

\begin{tabular}{ccccc}
\hline Mean & Median & Mode & Standard Deviation & Skewness \\
\hline 92.375 & 92.5 & 90 & 3.92 & 0.439 \\
\hline
\end{tabular}

Table 5 shows that the average value on the input aspect is 92.375 ; the middle value of 92.5 ; the most value obtained is 90 . It is clear that the data has a standard deviation of 3.92 ; and a skewness value of 0.439 . Based on Table 5, the mean value is less than the median and higher than the mode. The distribution data is positive/right sloping (positive skewness). The size of the skewness is 0.439 . For evaluation, the value is changed to the ratio number. Skewness ratio $=$ skewness value/standard skewness error $=0.439 / 0.285=1.5$. Therefore, because the skewness ratio is between -2 to 2 , then the data distribution is normal. Frequency distribution data from the input aspects obtained in this research can be seen in Table 6 . 
Table 6. Frequency Distribution in Input Aspect

\begin{tabular}{|c|c|c|c|}
\hline Interval & Category & $\mathbf{F}$ & $\%$ \\
\hline$X<52.00$ & Very Low & 0 & 0 \\
\hline $65 \geq X \geq 52.00$ & Low & 0 & 0 \\
\hline $78.00 \geq X \geq 65$ & High & 0 & 0 \\
\hline$X \geq 78.00$ & Very High & 34 & 100 \\
\hline \multicolumn{2}{|c|}{ Amount } & 34 & 100 \\
\hline
\end{tabular}

Based on Table 6, $0(0 \%)$ of respondents are in the category of very low or strongly disagree; $0(0 \%)$ of respondents are in a low category or did not agree; $0(0 \%)$ of respondents are in the high category or agreed; and $34(100 \%)$ respondents are in the very high category or strongly agree. The value of achieving quality from competency certification in SMK N 2 Klaten from the input aspect can be seen in Table 7 .

Table 7. Value of Achieving Quality Input Aspect

\begin{tabular}{ccccc}
\hline Number of Respondents & Number of Statements & NPK & \% & Category \\
\hline 34 & 26 & 92.3 & 88.82 & Very High \\
\hline
\end{tabular}

Based on Table 7, the component of competency certification through LSP P-1 in SMK N 2 Klaten from the input aspect is included in the very high category with a quality achievement score of 92.3 with a percentage of $88.82 \%$. Achievement of the quality of input aspects is assessed on a scale of 1 to 4 . Data on the value of quality achievement in input aspects can be seen in Table 8 .

Table 8. Quality Achievement Value in the Input Aspect Indicator

\begin{tabular}{|c|c|c|c|c|}
\hline Indicator & Item & Value & Total Value & Category \\
\hline Assessors & $\begin{array}{l}1 \\
2 \\
3 \\
4 \\
5 \\
6 \\
7\end{array}$ & $\begin{array}{c}4 \\
3.37 \\
3.45 \\
3.2 \\
3 \\
3 \\
3\end{array}$ & 3.31 & High \\
\hline $\begin{array}{l}\text { Assessment } \\
\text { Tool }\end{array}$ & $\begin{array}{c}8 \\
9 \\
10 \\
11 \\
12\end{array}$ & $\begin{array}{c}3.6 \\
4 \\
4 \\
4 \\
3.7\end{array}$ & 3.6 & Very High \\
\hline $\begin{array}{l}\text { Competency } \\
\text { Test Place }\end{array}$ & $\begin{array}{l}13 \\
14 \\
15 \\
16 \\
17 \\
18 \\
19 \\
20\end{array}$ & $\begin{array}{c}4 \\
3.8 \\
4 \\
4 \\
4 \\
4 \\
4 \\
3.8\end{array}$ & 4 & Very High \\
\hline $\begin{array}{l}\text { Facilities and } \\
\text { Infrastructure }\end{array}$ & $\begin{array}{l}21 \\
22 \\
23 \\
24 \\
25 \\
26\end{array}$ & $\begin{array}{c}4 \\
3 \\
3 \\
4 \\
4 \\
3.8\end{array}$ & 3.43 & High \\
\hline
\end{tabular}

Based on Table 8, the items in the indicator criteria for assessors with the lowest quality are 3.2, that is, assessors have three times developed, planned, and implemented assessment tools. According to respondents, the importance of assessor quality in competency certification makes as- 
sessor criteria must be maintained at a minimum. The item which has the highest quality value of the assessor indicator is 4 . The suitability of the competency certification test through the LSP P-1 at SMK N 2 Klaten from the assessor's input aspect has a value of achieving indicator quality of 3.31. This means that the competency assessor certification test has criteria that are following the requirements. This follows the requirements for implementing competency certification so that the competency certification assessor can provide an assessment correctly.

In the assessment instrument indicators, the achievement value of quality items regarding the assessment equipment is prepared by the assessor team, and the competency assessment tool is updated and developed periodically or according to their respective needs to get a score of 4 . The suitability of the assessment kit in competency certification in SMK N 2 Klaten, that is, with an achievement value of item quality of 3.6, means that in the completeness of the assessment tools in the category are very appropriate. This means that the assessment tools are very good. However, according to respondents, there were still too many assessment documents that had to be prepared to make it less than optimal in preparation.

In the indicators of competency test facilities and infrastructure, the value of the quality of the items concerning TUK following the scope of the certification scheme referred and verified TUK each obtained a score of 4 and 3.8. The completeness of the competency test site, as well as facilities and infrastructure in the competency certification test that is with a quality achievement score of 4 and the achievement value of the quality of facility and infrastructure indicator points, is 3.43 , meaning that the completeness of the competency test site and facilities and infrastructure is very good. This means that the competency test is considered very feasible, but according to respondents, in this case, it is necessary to improve the indicators of procedures and equipment (number, quality of tools, materials) for competency testing.

According to Kaufman and Thomas (2009, pp. 116-117), evaluation of inputs is used to identify what is needed to determine the purpose of the evaluation being carried out. The input aspect also helps to determine the procedures and design for implementing the program. The research results on the input aspect indicate the need for improvement in the indicators of the suitability of the assessors' criteria with the requirements so that it is necessary to train all prospective assessors.

\section{Evaluation of Competency Certification Test through the LSP P-1 at SMK N 2 Klaten: Review of the Aspect of Process}

Data on the competency certification component of the process aspects were obtained from instruments in the form of questionnaires. Respondents are all parties involved in the implementation of the LSP P-1, consisting of the principal as the person in charge/board of supervisors, secretary, treasurer, certification manager, scheme committee chair, LSP chair, TUK head, and assessors. The indicators contained in this aspect of the process are Competency Certification Test Preparation, Competency Certification Test Time, Competency Certification Test Procedure, Assessment System. Data on this component were obtained from the results of the questionnaire given to 71 respondents. The questionnaire has 20 statements. Descriptive statistical data from the process aspects obtained in this research can be seen in Table 9.

Table 9. Descriptive Statistics of Process Aspect

\begin{tabular}{ccccc}
\hline Mean & Median & Mode & Standard Deviation & Skewness \\
\hline 67.33 & 67.5 & 71 & 3.7 & 0.177 \\
\hline
\end{tabular}

Based on Table 9, it can be seen that the mean price on the aspect of the process is 67.33; the middle value of 67.5 ; the most value obtained is 71 ; the data has a standard deviation of 3.7 ; and skewness value of 0.177 . Based on Table 9, the mean value is less than the median and higher than the mode, then the distribution data is positive/italicized (positive skewness). The size of the skewness is 0.177 . For valuation, the value is changed to the ratio number. Skewness ratio is $=$ skewness value/standard skewness error $=0.177 / 0.285=0.62$. Because the skewness ratio is between -2 to $=$ 2 , the data distribution is normal. Data on the frequency distribution of aspects of the process obtained in this research can be seen in Table 10 . 
Table 10. Frequency Distribution in Process Aspect

\begin{tabular}{cccc}
\hline Interval & Category & F & $\%$ \\
\hline$X<38.00$ & Very Low & 0 & 0 \\
$47.5 \geq X \geq 38.00$ & Low & 0 & 0 \\
$57.00 \geq X \geq 47.5$ & High & 0 & 0 \\
$X \geq 57.00$ & Very High & 34 & 100 \\
\hline & Amount & 34 & 100 \\
\hline
\end{tabular}

Based on Table 10, $0(0 \%)$ of respondents are in the category of very low or strongly disagree; $0(0 \%)$ of respondents are in a low category or did not agree; $0(0 \%)$ of respondents are in the high category or agreed; and $34(100 \%)$ respondents are in the very high category or strongly agree. The value of achieving quality from competency certification in SMK N 2 Klaten from the aspect of the process can be seen in Table 11.

Table 11. Value of Achieving Quality Process Aspect

\begin{tabular}{ccccc}
\hline Number of Respondents & Number of Statements & NPK & \% & Category \\
\hline 34 & 20 & 67.33 & 88.59 & Very High \\
\hline
\end{tabular}

Based on Table 11, it can be seen that the component of competency certification test through LSP P-1 in SMK N 2 Klaten from the aspect of the process is included in the very high category with a quality achievement score of 67.33 with a percentage of $88.59 \%$. Achievement of the quality of input aspects is assessed on a scale of 1 to 4 . Data on the value of quality achievement in the input aspect can be seen in Table 12.

Table 12. Quality Achievement Value in the Process Aspect Indicator

\begin{tabular}{ccccc}
\hline Indicator & Item & Value & Total Value & Category \\
\hline Implementation of & 1 & 4 & 4 & Very High \\
Competency Certification Test & 2 & 3.3 & 3.47 & High \\
Competency Certification Test & 3 & 3.4 & & \\
Preparation & 4 & 3.2 & & \\
& 5 & 3 & & \\
& 6 & 3 & & \\
& 7 & 3 & & \\
& 8 & 3.5 & & \\
Competency Certification Test & 9 & 3.5 & & \\
Procedure & 10 & 3.7 & & \\
& 11 & 4 & & \\
Assessment System & 12 & 4 & & \\
& 13 & 3.8 & & \\
& 14 & 4 & & \\
& 15 & 3.8 & & \\
& 16 & 3.7 & 3.85 & \\
\hline
\end{tabular}

Based on Table 12, the items that have the lowest quality value of the competency certification preparation indicators are items 5,6 , and 7 with a value of 3 that in the implementation of competency certification is well prepared but in terms of the test material and test, the material is still lacking, so it needs to be added to maximum results. The competency certification test preparation through LSP P-1 from the aspect of the process regarding the preparation in the competency certification test has the achievement value of the indicator quality of 3.47. This means that competency certification preparation is suitable. 
The time of implementation in competency certification is to use the achievement value of the indicator quality of 4 . The research results on the process aspects show that the implementation of competency certification through LSP P-1 is very high, meaning that the competency certification has been well scheduled. The suitability of the procedure in competency certification has a value of achieving the quality of indicator items of 3.85. This means that the implementation procedures for competency certification are very appropriate. The assessment system in competency certification has a value of achieving the quality of indicator indicators of 3.4. This means that the assessment system is very good, by the guidelines, and the assessment system is honest and transparent.

According to Kaufman and Thomas (2009, pp. 116-117), process evaluation is specifically used to detect, identify the strengths and weaknesses of a program that occurs during the implementation of a program. Process evaluation is used as a record of the real implementation of a program. The results showed the implementation of competency certification from the aspect of the process in the excellent category, with several indicators that must be considered, namely in preparing materials and preparing competency test materials. Thus, it needs additional facilities and infrastructure for the implementation of competency certification and preparation of test materials and test materials must be adjusted to the package of questions.

\section{Evaluation of Competency Certification Test through the LSP P-1 atSMK N 2 Klaten: Review of the Aspect of Product}

Data on the competency certification component from the product aspect were obtained from the instrument in the form of a questionnaire. Respondents are all parties involved in implementing the LSP P-1 consisting of the principal as the person in charge/board of supervisors, secretaries, treasurers, certification managers, chair of the scheme committee, chair of the LSP, head of the TUK, and assessors. The indicators contained in the product aspects are the Results of Competency Certification Products and Competency Certification Certificates. Data on this component were obtained from the results of the questionnaire given to 71 respondents. The questionnaire has 11 statements. Descriptive statistical data from the product aspects obtained in this research can be seen in Table 13.

Table 13. Descriptive Statistics of Product Aspect

\begin{tabular}{ccccc}
\hline Mean & Median & Mode & Standard Deviation & Skewness \\
\hline 34.5 & 34.5 & 36 & 2.28 & 0.275 \\
\hline
\end{tabular}

Based on Table 13, the mean value on the product aspect is the same as the median value and is smaller than the mode value, then the distribution data is positive/tilted to the right (positive skewness). The size of the skewness is 0.275 . For valuation, the value is changed to the ratio number. Skewness ratio $=$ skewness value/standard skewness error $=0.275 / 0.285=0.9$. Because the skewness ratio is between -2 to +2 , the data distribution is normal. Frequency distribution data from product aspects obtained in this research can be seen in Table 14.

Table 14. Frequency Distribution in Process Aspect

\begin{tabular}{|c|c|c|c|}
\hline Interval & Category & $\mathbf{F}$ & $\%$ \\
\hline$X<22.00$ & Very Low & 0 & 0 \\
\hline $27.5 \geq X \geq 22.00$ & Low & 0 & 0 \\
\hline $33.00 \geq X \geq 27.5$ & High & 8 & 23.5 \\
\hline$X \geq 33.00$ & Very High & 26 & 76.5 \\
\hline \multicolumn{2}{|c|}{ Amount } & 34 & 100 \\
\hline
\end{tabular}

Based on Table 14, $0(0 \%)$ of respondents are in the category of very low or strongly disagree; $0(0 \%)$ of respondents are in a low category or did not agree; $8(23.5 \%)$ respondents are in the high category or agreed, and $26(76.5 \%)$ respondents are in the very high category or strongly agree. The achievement value of competency certification in SMK N 2 Klaten from the product aspect can be seen in Table 15 . 
Table 15. Value of Achieving Quality Product Aspect

\begin{tabular}{ccccc}
\hline Number of Respondents & Number of Statements & NPK & \% & Category \\
\hline 34 & 11 & 34.5 & 78.4 & High \\
\hline
\end{tabular}

Based on Table 15, it can be seen that the component of competency certification through LSP P-1 in SMK N 2 Klaten in terms of product aspects is included in the high category with a quality achievement score of 34.5 with a percentage of $78.4 \%$. Table 16 shows the acquisition of the quality value of product aspects with a scale of 4 .

Table 16. Quality Achievement Value in the Process Aspect Indicator

\begin{tabular}{ccccc}
\hline Indicator & Item & Value & Total Value & Category \\
\hline Competency Certification & 1 & 4 & 3.6 & Very High \\
Test Results & 2 & 3.3 & & \\
& 3 & 3.4 & & \\
Competency Certification & 4 & 3.2 & 2.5 & Low \\
Test Products & 5 & 1.9 & & \\
Competency Certification & 6 & 3 & 3 & \\
Test Certificates & 7 & 3 & & \\
& 8 & 3.6 & & \\
& 9 & 1.6 & & \\
& 10 & 3.6 & & \\
\hline
\end{tabular}

Based on Table 16, the competency test document indicators that have the lowest quality value are from the psychomotor aspects that are equal to 3.3. The achievement of the competency certification test through LSP P-1 in Klaten Regency in terms of product aspects regarding the results in competency certification has a value of achieving the quality indicator indicators of 3.6. This means that competent assessments are proven by the value of competency certification results in the excellent category. However, the psychomotor aspects need to be improved to be in accordance with the competency qualifications.

The item from the lowest competency certificate indicator is point 9 regarding the issuance of certificates with a value of 1.6. This means that respondents disagree with the issuance of certificates. The achievement of the competency certification certificate is with the achievement value of the indicator quality of 3 . This means that the recognition of the business world and the industrial world of the competency certificate is still low, so cooperation with the business world and industry is needed so that the competency certificate is truly recognized.

According to Wirawan (2011, pp. 92-94), product evaluation seeks to answer whether the program was successful. The time of implementation when the program is complete. The results showed that from the aspect of product competency, certification tests must be considered in psychomotor because it greatly affects assessment competence assessment. Product reliability must be adjusted to the needs and demands of the product because the certification of quality/ideal competence is expected to be able to produce competent candidates for the workforce. Other aspects of the product that must be considered are competency certificates. Ideally, competency certificates are issued no later than two weeks after the implementation of competency certification but based on the testimony of all respondents, it is more than the specified time.

\section{CONCLUSION}

Based on the problem, research objectives, results of analysis and discussion that have been presented, it can be concluded that (1) the implementation of competency certification through LSP P-1 in SMK N 2 Klaten in terms of the suitability of context aspects is included in the very appropriate category $(83.93 \%)$, i.e., relevant to the policies and objectives of competency certification. (2) The implementation of competency certification through LSP P-1 at SMK N 2 Klaten in terms of suitability of input aspects is included in the very appropriate category $(88.82 \%)$, which meets 
the criteria of assessors, completeness of assessment equipment, place of competency test, and test infrastructure competence. (3) The implementation of competency certification through LSP P-1 in SMK N 2 Klaten is reviewed from the aspect of the process included in the very appropriate category $(88.59 \%)$, namely the suitability of the implementation procedures, time allocation, preparation, and evaluation system in competency certification. (4) The implementation of competency certification through LSP P-1 at SMK N 2 Klaten in terms of achievement of product aspects is included in the very high category (78.4\%), namely the achievement of competency certification products and competency certificates.

Implications in this research are as follows. (1) The results of the study indicate that in the implementation of competency certification related to policies and objectives are very appropriate, but from some of these indicators, the implementation of competency certification does not yet reflect the competence of students to engage in national and international scale industries, employment opportunities for graduates more in the local industry, even on a national scale is still low. Thus, cooperation is needed with the industry and the need for competency standards/criteria in accordance with the industry, both local, national, and international scale. (2) The results of the study indicate that the implementation of competency certification in terms of input is already very appropriate, but from some of these indicators, it is still not optimal, namely regarding the suitability of assessors' criteria and requirements. Thus, it needs training for prospective assessors. (3) The results of the study indicate that in the implementation of competency certification in terms of the implementation process, there are still some shortcomings, namely the limitations of infrastructure and the number of equipment and materials that are less than the number of test participants, so the need for additional infrastructure is quite urgent. (4) The results of the study show that in the implementation of competency certification in terms of products, it is shown that the psychomotor aspects of the test participants are lower than other aspects, this is because there are still many test participants who have not mastered the theories related to competency certification. Besides, in terms of products, the implementation of competency certification through LSP P-1 is still constrained due to funding issues. Therefore, comprehensive guidance is needed for students, and additional funding is needed.

\section{REFERENCES}

BNSP Regulation No. 1/BNSP/III/2014 on the Guidelines for Conformity Assessment - General Requirement for Professional Certification Agency, (2014).

BNSP Regulation No. 10/BNSP.303/XI/2013 on the General Requirement Guidelines for Assessors, Master Assessors, and Lead Assessors, (2013).

Colardyn, D. (2009). The certification of competencies. In R. Maclean \& D. Wilson (Eds.), International handbook of education for the changing world of work: Bridging academic and vocational learning (pp. 2777-2792). Springer.

Dobson, G. (2003). A guide to writing competency-based training materials. . Commonwealth of Australia - National Volunteer Skills Centre.

Kaufman, R., \& Thomas, S. (2009). Evaluation without fear. New Viewpoints.

Kuswana, W. S. (2013). Dasar-dasar pendidikan vokasi dan kejuruan. Alfabeta.

Ministry of Education and Culture. (2017). 327 SMK sudah jadi lembaga sertifikasi profesi. LPPKS Ministry of Education and Culture of Republic of Indonesia. http://lppks.kemdikbud. go.id/id/kabar/327-smk-sudah-jadi-lembaga-sertifikasi-profesi

Rizkiyah, N. F., Mariana, R. R., \& Soekopitojo, S. (2018). Sertifikasi asesor kompetensi guru produktif program keahlian Tata Boga dalam pelaksanaan uji sertifikasi kompetensi. Jurnal Pendidikan: Teori, Penelitian, Dan Pengembangan, 3(6), 708-714. https://doi.org/10.17977 /jptpp.v3i6.11110 
Rodin, R. (2015). Sertifikasi uji kompetensi sebagai upaya peningkatan profesionalitas pustakawan. Jurnal Kepustakawanan Dan Dokumentasi Informasi, 14(2), 15-24. https://journal.unhas. ac.id/index.php/jupiter/article/view/33

Stufflebeam, D. L., \& Zhang, G. (2017). The CIPP evaluation model: How to evaluate for improvement and accountability. The Guilford Press.

Suharto, S. (2015). Evaluasi pelaksanaan kegiatan uji sertifikasi kompetensi keahlian administrasi perkantoran. Prosiding Seminar Nasional Pendidikan Administrasi Perkantoran, 37-47. https://jurnal.uns.ac.id/snpap/article/view/26528

Tissot, P. (2004). The terminology of vocational training policy: A multilingual glossary for an enlarged Europe. Office for Official Publications of the European Communities.

Wirawan, W. (2011). Evaluasi teori model standar aplikasi dan profesi: Contoh aplikasi evaluasi program: Pengembangan sumber daya manusia, program nasional pemberdayaan masyarakat (PNPM) mandiri perdesaan, kurikulum, perpustakaan, dan buku teks. Rajawali Pers.

Yusuf, A. R., \& Mukhadis, A. (2018). Model pengembangan profesionalitas guru sesuai tuntutan revitalisasi pendidikan vokasi di Indonesia. Lectura: Jurnal Pendidikan, 9(2), 130-139. https://doi.org/10.31849/lectura.v9i2.1613

Yusuf, F. T. (2008). Evaluasi program dan instrumen evaluasi untuk program pendidikan dan penelitian. Rineka Cipta. 